\title{
Rearing system effects on live weight gain of Large White turkeys
}

\author{
H. Inci ${ }^{1 \#}$, Ş. Çelik ${ }^{1}$, B. Söğüt ${ }^{2}$, T. Şengül ${ }^{1}$, A. Y. Şengül ${ }^{1}$, \& M. İlkaya ${ }^{1}$ \\ ${ }^{1}$ Bingol University, Faculty of Agriculture, Department of Animal Science, Bingol, Turkey \\ ${ }^{2}$ Bandirma Onyedi Eylül University, Bandirma Vocational School, Food Processing Department Bandırma, Turkey
}

(Submitted 4 May 2020; Accepted 4 July 2020; Published 7 December 2020)

\begin{abstract}
Copyright resides with the authors in terms of the Creative Commons Attribution 4.0 South African Licence.
See: http://creativecommons.org/licenses/by/4.0/za

Condition of use: The user may copy, distribute, transmit and adapt the work, but must recognise the authors and the South African Journal of Animal Science.
\end{abstract}

\begin{abstract}
The aim of this study was to determine the effect of three production systems on live weight gain (LWG) of white turkeys by repeated measures analysis of variance (ANOVA) and profile analysis. A total of 81 turkey poults were assigned to intensive ( 7 male and 19 female), semi-intensive ( 9 male and 19 female) and extensive groups (11 male and 16 female) at one day old. The poults were wing-banded at day 1 after hatching and weighed individually each week through 16 weeks old. The birds were managed similarly through eight weeks old. After that time, the intensive group was fed concentrated feed indoors. The birds of the semi-intensive group had access to pasture for eight hours a day, and received $50 \%$ of the concentrated feed that was consumed by the intensive group. The birds in the extensive group were kept outdoors with shade and grazed on pasture, but did not receive concentrated feed. The bi-weekly LWG of the extensive, intensive and semi-intensive groups were $1191.4 \mathrm{~g}, 990.6 \mathrm{~g}$ and $872.1 \mathrm{~g}$, respectively. Through the 16 weeks of the trial, the effects on LWG of production system, age, and interaction of age and production system were highly significant $(P<0.01)$ in the repeated measures ANOVA. The profile analysis also showed highly significant $(P<0.01)$ production system effects and interaction of production system and age on LWG. Scheffe's test indicated that the intensive, semi-intensive, and extensive treatments differed $(P<0.05)$.
\end{abstract}

Keywords: growth, profile analysis, repeated measurement analysis of variance

\#Corresponding author: hakaninci2565@gmail.com

\section{Introduction}

Turkeys complement other sources of animal protein and are becoming increasingly important to close the gap between consumer demand and supply (Kırkpınar \& Mert, 2004; Ekinci, 2015; Küçükbayrak, 2015). The availability in the marketplace of less expensive turkey meat has led to increased production and consumption compared with red meats (Gülaç, 2011). Intensified production systems have resulted in increased live weight and carcass yield, whereas the ability to reduce feed costs by grazing in pasture is another important advantage of turkey production (Ekinci, 2015).

The efficiency of turkey production may be enhanced by their ability to select among dietary ingredients. Erener et al. (2006) presented raised rates of gain in turkeys using a free preference system. Live weight daily gain was increased for birds that were choice-fed wheat than for turkey poults that were choice-fed maize. However, Bennett and Classen (2003) suggested that reports of successful exploitation of diet selection were probably from excessive nutrient levels in the diet, instead of whole grains.

Various statistical methods have been applied to analyse LWG over time. Repeated measures ANOVA is the classical method (Krueger \& Tian, 2004). Its implementation as a general linear mixed model accommodates missing data. Profile analysis is an extension of repeated measures ANOVA in which slopes between adjacent weights are compared. It was used previously to assess the influence of three lighting programmes on American Bronze turkeys (Mendes et al., 2005). Thus, the aim of this study was to compare two methods of data analysis, namely repeated measures ANOVA and profile analysis in assessing the effects of three production systems (intensive, semi-intensive and extensive) on LWG of turkeys over time.

\section{Materials and methods}

Bingöl University Experimental Animals Ethics Committee reviewed and approved this project (BAP88-220-2014). 
A total of 81 turkey poults were assigned to intensive ( 7 male and 19 female), semi-intensive ( 9 male and 19 female) and extensive groups (11 male and 16 female) at one day old. The poults were wing-banded with a unique identification number on the day after hatching, and were weighed weekly through 16 weeks old. The birds of the intensive group were fed concentrated feed indoors. The semi-intensive group had access to pasture for eight hours a day and received $50 \%$ of the concentrated feed that was consumed by the intensive group. The extensive group were kept outdoors with shade and grazed on pasture, but did not receive concentrated feed.

The experimental unit comprised turkeys in the production system, and observations of their LWG were recorded at two-week intervals. Thus, there were three levels of production system and eight levels of age. Because repeated measures result from the serial measurement of a single characteristic (e.g., live weight) on an experimental unit (Field, 2013), a repeated measure ANOVA (Montgomery, 2013) was used to analyse the differences in live weight across the ages of the birds. In this analysis, the mathematical model was:

$$
Y_{i j k}=\mu+A_{i}+C_{k(i)}+B_{j}+A B_{i j}+\varepsilon_{m(i j k)}
$$

where: $\quad Y_{i j \mathrm{k}}=\mathrm{LWG}$ of the kth turkey that had been subjected to treatment $\mathrm{i}$ at age $\mathrm{j}$;

$\mu=$ the overall mean LWG;

$\mathrm{A}_{i}:=$ the fixed effect of production system i;

$C_{\mathrm{k}(\mathrm{i})}=$ the random effect of bird $\mathrm{k}$ within production system $\mathrm{i}$ (error $\mathrm{A}$ for testing production system effects);

$B_{\mathrm{j}}=$ the fixed effect of age $\mathrm{j}$;

$\mathrm{AB}_{i j}=$ the interaction of production system $\mathrm{i}$ with age $\mathrm{j}$; and

$\varepsilon_{m(i j \mathrm{k})}=$ the difference between the observations and their expectation based on the model (error $\mathrm{B}$ for testing age and age by production system interaction effects).

These data were also analysed using profile analysis (Cronbach \& Gleser, 1953; Stanton \& Reynolds, 2000). This analysis is the multivariate equivalent of the repeated measures ANOVA. Statistical assumptions implied required in profile analysis are i) multivariate normal distribution of the response variables (Jarek, 2012), ii) homogeneity of their variance-covariance matrices (French et al., 2015) and iii) linear relationships among them (Tabachnick \& Fidell, 2015).

The differences between the groups were determined by Scheffe's multiple comparison test (Şenoğlu \& Acıtaş, 2010). Scheffe's procedure treats the mean square for any single contrast if it had the degrees of freedom of the between groups mean square (Oehlert, 2010).

Effect sizes were calculated to determine whether statistically significant results were large enough to be practically important (Mendes, 2013). The effect size $\left(\eta^{2}\right)$ was defined as:

$$
\eta 2=\frac{S S_{\text {effect }}}{S S_{\text {effect }}+S S_{\text {error }}}
$$

where: $\quad S_{\text {effect }}=$ the sums of squares for the effect of interest, and

$\mathrm{SS}_{\text {error }}=$ the sums of squares for the associated error term (Tabachnick \& Fidell, 2015).

All data analyses were conducted with SPSS 22.0 (IBM Corp., Armonk, New York, USA).

\section{Results and Discussion}

The significance of the interaction of production system with age indicated that the turkeys grew at different rates over time. Thus in interpreting these data, the effects of age and production system need to be considered jointly. For these data, the age effects on live weight were compared within production system and the effects of production system were compared within age. Age had the largest effect, although the effects of production system and interaction were substantial and more similar to each other. The repeated measures ANOVA table is shown in Table 1. 
Table 1 Analysis of variance for repeated measurements of live weight gain of turkeys managed in intensive, semi-intensive and extensive production systems

\begin{tabular}{lrrrrrc}
\hline Source & \multicolumn{1}{c}{ SS } & \multicolumn{1}{c}{ df } & MS & F & $P$-value & $\eta^{2}$ \\
\hline Production system (PS) & 11015497 & 2 & 5507749 & 74.9 & $<0.001$ & 0.512 \\
Error A & 10500377 & 78 & 134620 & & & \\
Weeks of age (A) & 173123778 & 7 & 24757392 & 336.9 & $<0.001$ & 0.791 \\
PS*A interaction & 44468384 & 14 & 3176313 & 43.2 & $<0.001$ & 0.492 \\
Error B & 45859369 & 624 & 73493 & & & \\
\hline
\end{tabular}

SS: sum of squares, df: degrees of freedom, MS: mean square, $\eta^{2}$ : effect size

Differences between groups were not expected through the eighth week, because the poults were all kept indoors., However, LWG was highest for birds allocated to the extensive system at the 2nd, 4th, 6 th, $8^{\text {th }}$, and 16th weeks, for those allocated to the intensive system at the 10th and 14th weeks, and for those in the semi-intensive system at week 12 (Table 2). The greater performance of birds that were subjected to the extensive environment might have resulted from the allocation of more males to that group. At the eighth week, when the birds pf the semi-intensive and extensive groups were provided outdoor access, their performance showed a marked decrease, which might have resulted from adaptation to the new environmental circumstances. Other than this two-week period, the turkeys in the intensive and semiintensive systems generally grew at an increasing rate over the experiment. However, the LWG of turkeys in the extensive system remained lower at $10-12$ and $12-14$ weeks. At the 16th week, the turkeys in the intensive production system were heavier than those in the semi-intensive and extensive systems. Turkeys in the extensive system were lightest at the end of the experiment.

Table 2 Bi-weekly growth rates of turkeys managed in intensive, semi-intensive and extensive production systems

\begin{tabular}{crrr}
\hline \multirow{3}{*}{ Weeks } & \multicolumn{3}{c}{ Production system } \\
\cline { 2 - 4 } & Intensive $(\mathrm{N}=26)$ & Semi-intensive $(\mathrm{N}=28)$ & Extensive $(\mathrm{N}=27)$ \\
\hline $0-2$ & $165.4 \pm 7.2$ & $176.1 \pm 6.9$ & $190.0 \pm 7.0$ \\
$2-4$ & $426.2 \pm 17.6$ & $453.9 \pm 17.0$ & $459.8 \pm 17.3$ \\
$4-6$ & $899.5 \pm 31.0$ & $851.2 \pm 29.9$ & $906.7 \pm 30.4$ \\
$6-8$ & $1388.2 \pm 42.0$ & $1321.7 \pm 40.4$ & $1519.2 \pm 41.2$ \\
$8-10$ & $1806.8 \pm 44.1$ & $624.9 \pm 42.5$ & $96.7 \pm 30.6$ \\
$10-12$ & $1422.2 \pm 59.2$ & $1476.9 \pm 57.1$ & $890.4 \pm 58.1$ \\
$12-14$ & $1390.8 \pm 76.5$ & $1375.6 \pm 73.7$ & $830.3 \pm 75.0$ \\
$14-16$ & $2031.9 \pm 91.4$ & $1644.7 \pm 88.1$ & $2083.4 \pm 89.7$ \\
\hline
\end{tabular}

Estimates of the correlations between the bi-weekly observations of LWG are presented in Table 3 . They averaged 0.15. In repeated measures ANOVA, equivalence of covariance matrices within treatments were assumed for valid tests of significance. In the present experiment, Box's test for equivalence of the covariance matrices indicated that they were homogeneous $(F=1.02, P=0.11)$. Levene's test indicated the residual variances were homogenous at each age $(P=0.96-P=0.08)$. 
Table 3 Estimates of correlation between measurements of bi-weekly live weight gain of turkeys managed in intensive, semi-intensive and extensive production systems

\begin{tabular}{llllllll}
\hline Weeks & $2-4$ & $4-6$ & $6-8$ & $8-10$ & $10-12$ & $12-14$ & $14-16$ \\
\hline $0-2$ & $0.370^{* *}$ & $0.417^{* *}$ & 0.173 & $-0.219^{*}$ & -0.036 & -0.169 & $0.266^{*}$ \\
$2-4$ & 1 & $0.602^{* *}$ & $0.377^{* *}$ & -0.163 & 0.083 & -0.091 & 0.129 \\
$4-6$ & 1 & $0.485^{* *}$ & 0.064 & 0.132 & -0.029 & $0.271^{*}$ \\
$6-8$ & & 1 & -0.133 & 0.000 & 0.026 & $0.434^{* *}$ \\
$8-10$ & & & 1 & $0.504^{* *}$ & $0.408^{* *}$ & 0.111 \\
$10-12$ & & & & 1 & $0.463^{* *}$ & -0.059 \\
$12-14$ & & & & & 1 & $-0.247^{*}$ \\
$14-16$ & & & & & & 1 \\
& & & & & & &
\end{tabular}

An alternative to repeated measures ANOVA is profile analysis. Profile analysis asks three questions about the data (Rencher, 2002). In the context of this experiment, the questions were these. i) Do the birds in the production systems respond equally over time? ii) Do the production systems respond in a parallel way over time? iii) Are the responses to the production systems constant over time? Four alternative test statistics were used to test the multivariate hypotheses, namely Pillai's trace, Wilks' lambda, Hotelling's trace and Roy's largest root.

The first of the questions could be addressed by a simple comparison of means across all time points for each of the systems. This is equivalent to the test of production system effects in the repeated measures ANOVA. The birds in the intensive system had an average bi-weekly increase in live weight of $1191.4 \mathrm{~g}$, which was significantly greater than the average LWG of $990.6 \mathrm{~g}$ attained by the birds in the semi-intensive system, which was significantly greater than the average bi-weekly increase in live weight of $872.1 \mathrm{~g}$ for birds in the extensive system.

The question of parallel responses was addressed by the multivariate test of the interaction of production system effects with age. Each of the four tests of significance led to the same conclusion: growth rates over time were not parallel for the three systems. The results of the multivariate test of the production system by age interaction effects are presented in Table 4

Table 4 Multivariate tests of significance of the production system by age interaction effects on bi-weekly live weight gain of turkeys

\begin{tabular}{lrrrrrr}
\hline Test statistic & value & $\mathrm{F}$ & $\mathrm{df}_{\mathrm{n}}$ & $\mathrm{df}_{\mathrm{d}}$ & $P$-value & $\eta^{2}$ \\
\hline Pillai's trace & 1.477 & 29.446 & 14 & 146 & $<0.001$ & 0.982 \\
Wilks' lambda & 0.033 & 46.377 & 14 & 144 & $<0.001$ & 0.982 \\
Hotelling's trace & 13.874 & 70.361 & 14 & 142 & $<0.001$ & 0.982 \\
Roy's largest root & 12.651 & 131.930 & 7 & 73 & $<0.001$ & 0.982
\end{tabular}

$\mathrm{df}_{\mathrm{n}}$ : degrees of freedom for the numerator of the $\mathrm{F}$ statistic, $\mathrm{df}_{\mathrm{d}}$ : degrees of freedom for the denominator of the $\mathrm{F}$ statistic, $\eta^{2}$ : effect size

Finally, the question of responses being constant over time was addressed by the multivariate test of age effect (Table 5). Again, each of the four test statistics led to the general conclusion that LWG was not constant over time. 
Table 5 Multivariate tests of significance of age effects on bi-weekly live weight gain of turkeys

\begin{tabular}{lrccccc}
\hline Test statistic & value & $\mathrm{F}$ & $\mathrm{df}_{\mathrm{n}}$ & $\mathrm{df}_{\mathrm{d}}$ & $P$-value & $\eta^{2}$ \\
\hline Pillai's trace & 0.982 & 551.202 & 7 & 72 & $<0.001$ & 0.738 \\
Wilks' lambda & 0.018 & 551.202 & 7 & 72 & $<0.001$ & 0.818 \\
Hotelling's trace & 53.589 & 551.202 & 7 & 72 & $<0.001$ & 0.874 \\
Roy's largest root & 53.589 & 551.202 & 7 & 72 & $<0.001$ & 0.927
\end{tabular}

$\mathrm{df}_{n}$ : degrees of freedom for the numerator of the $\mathrm{F}$ statistic, $\mathrm{df}_{\mathrm{d}}$ : degrees of freedom for the denominator of the $\mathrm{F}$ statistic, $\eta^{2}$ : effect size

The profile graph is presented in Figure 1. The lines with different slopes at various points in time suggest a significant effect for parallelism (the groups have different LWG profiles for age). The variations in slope are great, ranging from large positive to large negative values, and thus explain the highly significant effect that was found for the production system by age interaction or equivalently the parallel patterns of LWG across production systems.

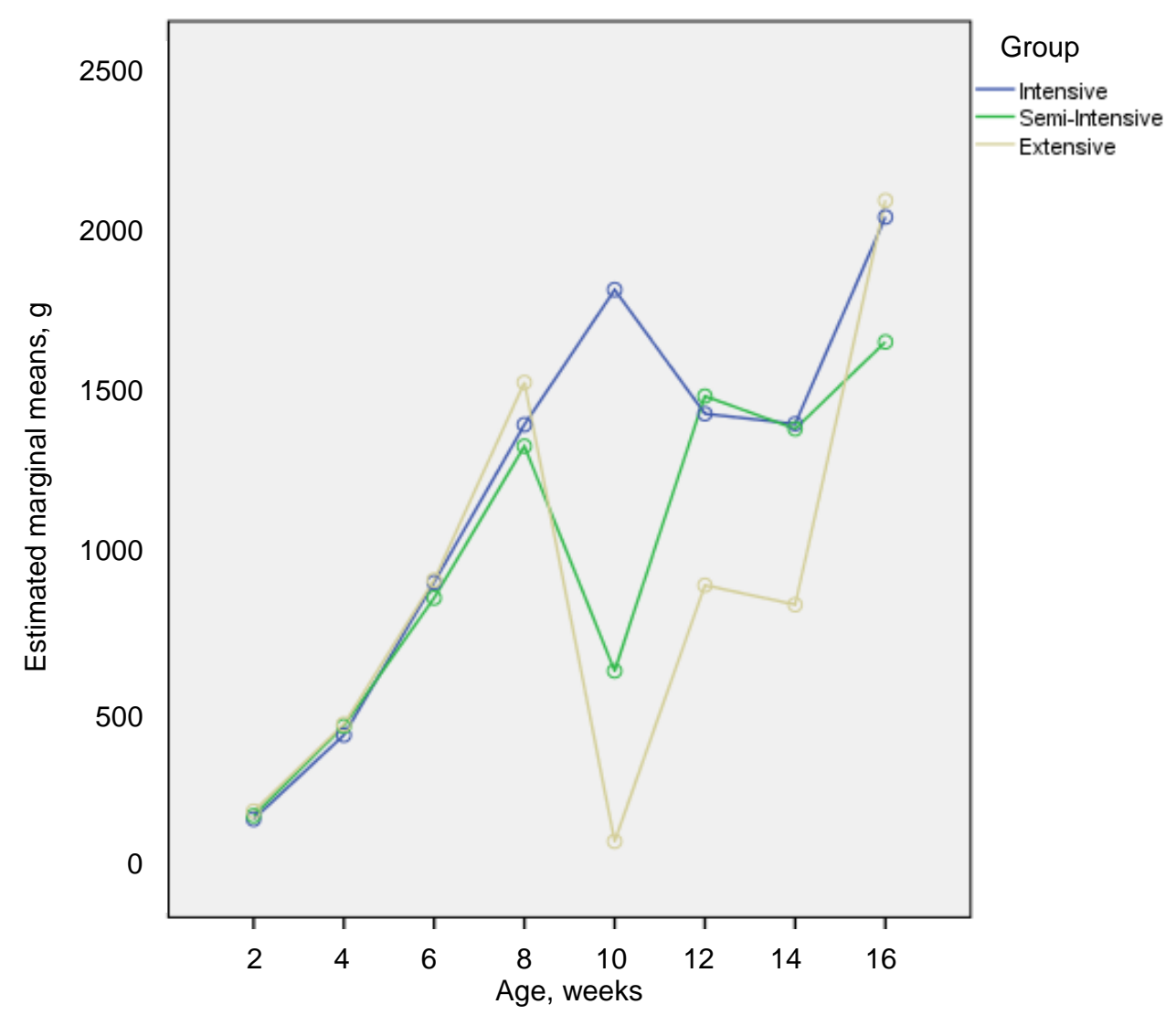

Figure 1 Profile plot detailing live weight gains attained by turkeys in intensive, semi-intensive and extensive production systems

In Ersoy et al. (2006) bronze turkey poults were fed a starter diet from hatch to 7 weeks old, then a grower diet in weeks 8 and 9, followed by a grower diet at 25 per cent of the previous level and ad libitum wheat for another two weeks, after which the birds were grazed on pasture. They found that males birds grew at a bi-weekly rate of $671.8 \mathrm{~g}$ between weeks 11 and 16 , while females grew at a rate of $490.6 \mathrm{~g}$ over the same age interval. Karki (2005) and Oblakova et al. (2008) likewise documented substantial effects of sex on the growth of turkeys through 16 weeks old. Thus a sex effect may explain why the extensively 
managed group, with the greatest number of male turkeys assigned to it, had higher LWG during the in first eight weeks than the other two groups in this study.

Ersoy et al. (2007) found that between 1 and 10 weeks old, turkeys grew from an average weight of $98.6 \mathrm{~g}$ to $2179.5 \mathrm{~g}$, indicating a bi-weekly LWG of $208.1 \mathrm{~g}$. Similarly, Sharma et al. (2018) observed an average bi-weekly rate of LWG $216.3 \mathrm{~g}$. Ersoy et al. (2007) reported that from 11 to 24 weeks old, tom turkeys increased in weight from $2228.0 \mathrm{~g}$ to $7754.9 \mathrm{~g}$, and hen turkeys increased in weight from $1847.6 \mathrm{~g}$ to $5541.1 \mathrm{~g}$. These changes in weight implied an average bi-weekly LWG of $709.3 \mathrm{~g}$, which was less than the level of performance that was achieved in the production systems in the present study.

In documenting differences among varieties, Işguzar (2003) reported that commercial white turkeys grew at a bi-weekly rate of $1308.8 \mathrm{~g}$ from hatching to 14 weeks old and that bronze turkeys grew at a biweekly rate of 624.8 over the same period. In evaluating two strains of commercial turkeys (British United Turkey and Nicholas), Brenøe and Kolstad (2000) observed that the strains did not differ in live weight with an average bi-weekly LWG of $1584.4 \mathrm{~g}$ between 4 and 17 weeks old, a value which was slightly higher than the performance that was achieved in the intensive production system of the present study.

Ad libitum or limit-feeding methods may be applied in feeding turkeys (Tumova et al., 2002; Mejia et al., 2010; Mejia et al., 2011; Sgavioli et al., 2013). Cetin et al. (2001) indicated that feed could be restricted to turkeys at up to $14 \%$ of ad libitum without lowering LWG. When the turkeys were grazed for eight hours a day, significantly decreased feed consumption was observed compared with the intensive system and therefore the semi-intensive system may be more economical (Özer \& Özbey, 2013). Grimes et al. (2007) also stated that turkeys could be raised on pasture once they reached 1.5 and 2 months old.

Karki (2005) found the optimal age at slaughter was 16 weeks, which was consistent with the endpoint of the present study. The effects of compensatory growth in turkey (Tumova et al., 2002) may offset some of the adverse impacts of the environmental change at the eighth week when the birds allocated to the semiintensive and extensive treatments were provided outdoor access. However, termination of this study at 16 weeks old did not result in full compensation for the change in environment.

\section{Conclusions}

Repeated measures ANOVA and profile analysis produced similar results in the analyses of the data from this study. However, because the effect sizes were consistently greater for the profile analysis compared with repeated measures ANOVA, profile analysis was deemed preferable. The interaction of production system with age was particular apparent when the turkeys were first provided with outdoor access. At 16 weeks old, turkeys that were managed intensively were heaviest.

\section{Acknowledgements}

Bingol University

The authors would like to thank Central Laboratory Research and Application Centre and the Research Fund of

\section{Authors' Contributions}

$\mathrm{HI}, \mathrm{BS}$ and TS contributed to the project idea, design and execution of the study. AYS and HI were in charge of laboratory analyses. $\mathrm{HI}, \mathrm{BS}, \mathrm{SC}$ and $\mathrm{MI}$ were responsible for supervising and writing the manuscript.

\section{Conflict of Interest Declaration}

The authors declare that there is no conflict of interests regarding the publication of this manuscript.

\section{References}

Anonymous. Profile analysis. http://userwww.sfsu.edu/efc/classes/biol710/manova/Profile-Analysis.pdf accessed 6 December 2020.

Bennett, C.D. \& Classen, H.L., 2003. Influence of whole wheat dilution on performance and carcass characteristics of male turkey. Journal of Applied Poultry Research 12, 468-475.

Brenøe, U.T. \& Kolstad, K., 2000. Body composition and development measured repeatedly by computer tomography during growth in two types of turkeys. Poultry Science 79, 546-552.

Çetin, M., Polat, U., Ak, I. \& Yalçın, A., 2001. Effects of restricted feeding on serum metabolites, electrolytes levels and live weight of turkeys. Journal of Faculty Veterinary Medicine 20,175-180.

Cronbach, L.J. \& Gleser, G., 1953. Assessing similarity between profiles. Psychological Bulletin 50, 456-473.

Ekinci, Y., 2015. Batman ili entansif koşullarında yapılan hindi yetiştiriciliğinin genel yapısı. Bingöl Üniversitesi Fen Bil. Enst. (Yüksek Lisans Tezi)

Erener, G., Ocak, N., Garipoğlu, A.V., Sahin, A. \& Öztürk, E., 2006. Feeding turkey poults with starter feed and whole wheat or maize in free choice feeding system: its effects on their performances. Asian-Australas Journal of Animal Science 19,86-90.

Ersoy, İ.E., Mendeş, M. \& Keskin, S., 2007. Estimation of parameters of linear and nonlinear growth curve models at early growth stage in California turkeys. Archiv fur Geflugelkunde 71,175-180.

Ersoy, İ.E., Mendeş, M. \& Aktan, S., 2006. Growth curve establishment for American Bronze turkeys. Arch. Tierz 
Dummerstorf 49,293-299.

Field, A.P., 2013. Discovering statistics using IBM SPSS statistics: And sex and drugs and rock'n' roll. 4th edition. Sage, London.

Grimes, J., Beranger, J. \& Walters, M., Pasturing Turkeys, chapter 3. In: How to Raise Heritage Turkeys on Pasture. American Livestock Breeds Conservancy, Pittsboro, North Carolina, USA.

Gülaç, Z.N., 2011. Dünya ve Türkiye'de hindi eti. Tarımsal Ekonomi ve Politika Geliştirme Enstitüsü Yayınları. ISSN 5,1303-8346.

İşgüzar, E., 2003. Growth, carcass traits and meat quality of bronze and white turkeys in Isparta Province of Turkey. Archiv fur Tierzucht 46,471-481.

Jarek, S., 2012. Nvnormtest: normality test for multivariate variables. R package version 0.1-9. http://CRAN.Rproject.org/package=mvnormtest

Karki, M., 2005. Growth, efficiency of feed utilization and economics of different rearing periods of turkeys. Nepal Agriculture Research Journal 6, 84-88.

Kırkpınar, F. \& Mert, S., 2004. Etlik hindi üretiminin temel ilkeleri. Hasad Hayvancılık Dergisi 2, 24-27.

Krueger, C. \& Tian, L., 2004. A comparison of the general linear mixed model and repeated measures ANOVA using a dataset with multiple missing data points. Biological Research for Nursing 6,151-157.

Küçükbayrak, U., 2015. Diyarbakır ili merkez ve ilçelerinde hindi yetiştiriciliğinin yapısı ve durumu. Bingöl Üniv. Fen Bilimleri Enstitüsü (Yüksek Lisans Tezi).

Mejia, L., Meyer, E.T., Utterback, C.W., Parsons, C.M. \& Koelkebeck, K.W., 2010. Evaluation of limit feeding corn and distillers dried grains with solubles in non-feed-withdrawal molt programs for laying hens. Poultry Science 89, 386392.

Mejia, L., Meyer, E.T., Studer, D.L., Utterback, P.L., Utterback, C.W., Parsons, C.M. \& Koelkebeck, K.W., 2011. Evaluation of limit feeding varying levels of distillers dried grains with solubles in non-feed-withdrawal molt programs for laying hens. Poultry Science 90, 321-327.

Mendes, M., Karabayır, A., Ersoy, I.E. \& Atasaglu, C., 2005. Effects of three different lighting programs on live weight change of Bronze turkeys under semi-intensive conditions. Archiv fur Tierzucht 48, 86-93.

Mendes, M., 2013. Uygulamalı bilimler için istatistik ve araştırma yöntemleri. Kriter Yayınevi, İstanbul, p. 626.

Montgomery, D.C., 2013. Design and analysis of experiments. 8th edition. John Wiley \& Sons, New York.

Oblakova, M., Lalev, M., Hristakieva, P. \& Georgieva, S., 2008. Effect of egg weight on the productive traits of hatched turkey poults not later than 16 weeks of age. Trakia Journal of Sciences 6, 83-87.

Oehlert, G.W., 2010. A first course in design and analysis of experiments. Library of Congress Cataloging-in-Publication Data. http://users.stat.umn.edu/ gary/book/fcdae.pdf

Özer, H. \& Özbey, O., 2013. Comparison of some production characteristics of the white and bronze turkeys (Meleagris gallopavo) under intensive and semi-intensive conditions. I. Growth performance. Fırat Üniversitesi Sağlık Bilimleri Veteriner Dergisi 27, 87-92.

Rencher, A.C., 2002. Methods of multivariate analysis. John Wiley \& Sons, USA.

Şenoğlu, B. \& Acıtaş, Ş., 2010. İstatistiksel deney tasarımı sabit etkili modeller. Nobel Yayın Dağıtım Tic. Ltd. Şti, Ankara.

Sgavioli, S., Filardi, R., da, S., Praes, M.F.F.M., Domingues, C.H., de, F., Pileggi, J., Andrade, P. de C., Boleli, C. \& Junqueira, O.M., 2013. Dietary fiber inclusion as an alternative to feed fasting to induce molting in commercial layers. Brazilian Journal of Poultry Science 15, 365-370.

Sharma, A., Shukla, P.K., Bhattacharyya, A., Kumar, U., Roy, D., Yadav, B. \& Prakash, A., 2018. Effect of dietary supplementation of sea buckthorn and giloe leaf meal on the body weight gain, feed conversion ratio, biochemical attributes, and meat composition of turkey poults. Veterinary World 11, 93-98.

Stanton, H.C. \& Reynolds, C.R., 2000. Configural frequency analysis as a method of determining Wechsler profile types. School Psychology Quarterly 15, 434-448.

Tabachnick, B.G. \& Fidell, L.S., 2015. Using multivariate statistics (Çev. Mustafa Baloğlu), Sixth edition. Nobel Akademik Yayıncılık Eğitim Danışmanlık Tic. Ltd. Şti. Ankara.

Tumova, E., Skřıvan, M., Skřivanová, V. \& Kacerovská, L., 2002. Effect of early feed restriction on growth in broiler chickens, turkeys and rabbits. Czech Journal of Animal Science 47, 418-428. 